\title{
Accounting
}

\section{The effects of macroeconomic factors on the rate of return of securities}

\author{
Kulanart Phutornkotara ${ }^{a}$ and Sakkarin Nonthapot ${ }^{b^{*}}$
}

${ }^{a}$ Faculty of Liberal Arts and Management Sciences, Kasetsart University, Chalermphrakiat Sakon Nakhon Province Campus, Thailand ${ }^{b}$ Faculty of Interdisciplinary Studies, Khon Kaen University,Nong Khai Campus, Thailand

\section{H R O N I C L E}

\section{Article history:}

Received: June 29, 2020

Received in revised format:

July 302020

Accepted: August 25, 2020

Available online:

August 25, 2020

Keywords:

Transport and Logistics

Services

Stock Exchange of Thailand

\section{A B S T R A C T}

This study aims to study the macroeconomic factors that affect the rate of return of securities in the transport and service category of the Stock Exchange of Thailand. The category comprises three groups: media services, tourism, hotel and recreation and transport and logistics. The study employs quarterly data from 2001 to 2019 estimated with the ARDL bounds testing approach. The results reveal that media services, tourism, hotel and recreation and transport and logistics groups in the tourism and service category were cointegrated with stock exchange volume (in thousands of shares), exchange rate, gold bullion price, interest rate and diesel oil price. This study also found the longterm equilibriums of the macroeconomic factors deviated from the short-run to long run for three groups. The gold bullion price factor is a major factor in determining the long run. This study suggests that the gold bullion price is an alternative indicator for investment. Investors in the transport and logistics group should focus on the exchange rate, the gold bullion price, the interest rate and the diesel oil price before investment. Investors should consider the level of the exchange rate before investing in the media service group in the Stock Exchange of Thailand while investors in the tourism, hotel and recreation group of the Stock Exchange of Thailand should be recognize the stock exchange volume.

\section{Introduction}

The transport and service industry has come to play a significant role in economy system in Thailand. Since 1995, the Asian Development Bank has supported transport and service sector in Thailand with a flagship program. In addition, the government of Thailand has also been supporting the industry over the same period. The transport and service sector of Thailand generates income from foreign visitors which is a source of income in the form of foreign currency, which is important for the economy of Thailand. The transport, tourism and service economy of Thailand can help to reduce the problem of deficits in international payments. It also helps to create careers and employment, which helps to distribute income and changes in economic structure at both the macro and micro levels (Nonthapot \& Srichaiyo, 2017). Moreover, from a social perspective, tourism services can also support the conservation and restoration of cultural features and the environment. It may also reduce the problem of the migration of local communities and encourages the use of otherwise unutilized resources to create products that can be sold. Presently, Thailand has income from sales of tourism and services products at a value of more than $15 \%$ of the national gross domestic product (GDP) (The World Bank, 2020). These factors may also be reflected in the growth in the transport and service

* Corresponding author

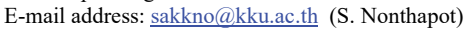


sector investment market at the Stock Exchange of Thailand. As a result of economic growth and domestic product and service prices, the number of foreign tourists in 2019 was about 40 million people, up from 10 million in 2001 (Fig. 1) while income has increased from about 10,000 million USD in 2001 to 62,000 million USD in 2019. Tourism is thus one of the main sources of income for Thailand. The expansion of the transport and service sectors in Thailand during 2001 - 2019 is a consequence of global economic and tourism growth, abundant natural resources, a greater variety of tourism offerings, low relative cost and supporting tourism promotion policy. In addition to the export of various products, the greatest beneficiaries of foreign tourism are tourism service providers, hotels and transportation, as well as various other services and recreation. The sustained growth in demand has led to the expansion of the transport and service industry and an increase in the number of tourism-related public companies listed on the Stock Exchange of Thailand.

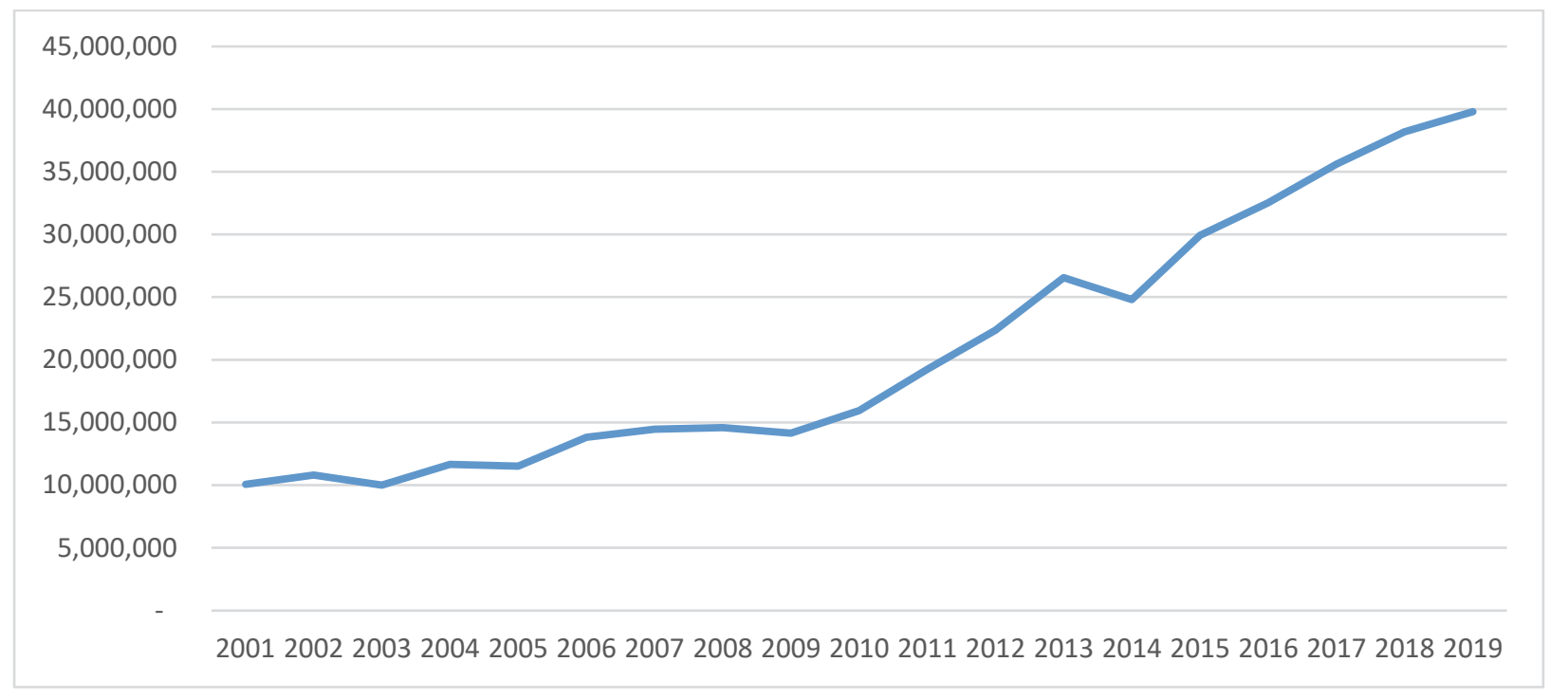

Source: CEIC Data (2020)

Fig. 1. Number of Foreign Tourists Visiting Thailand 2001-2019

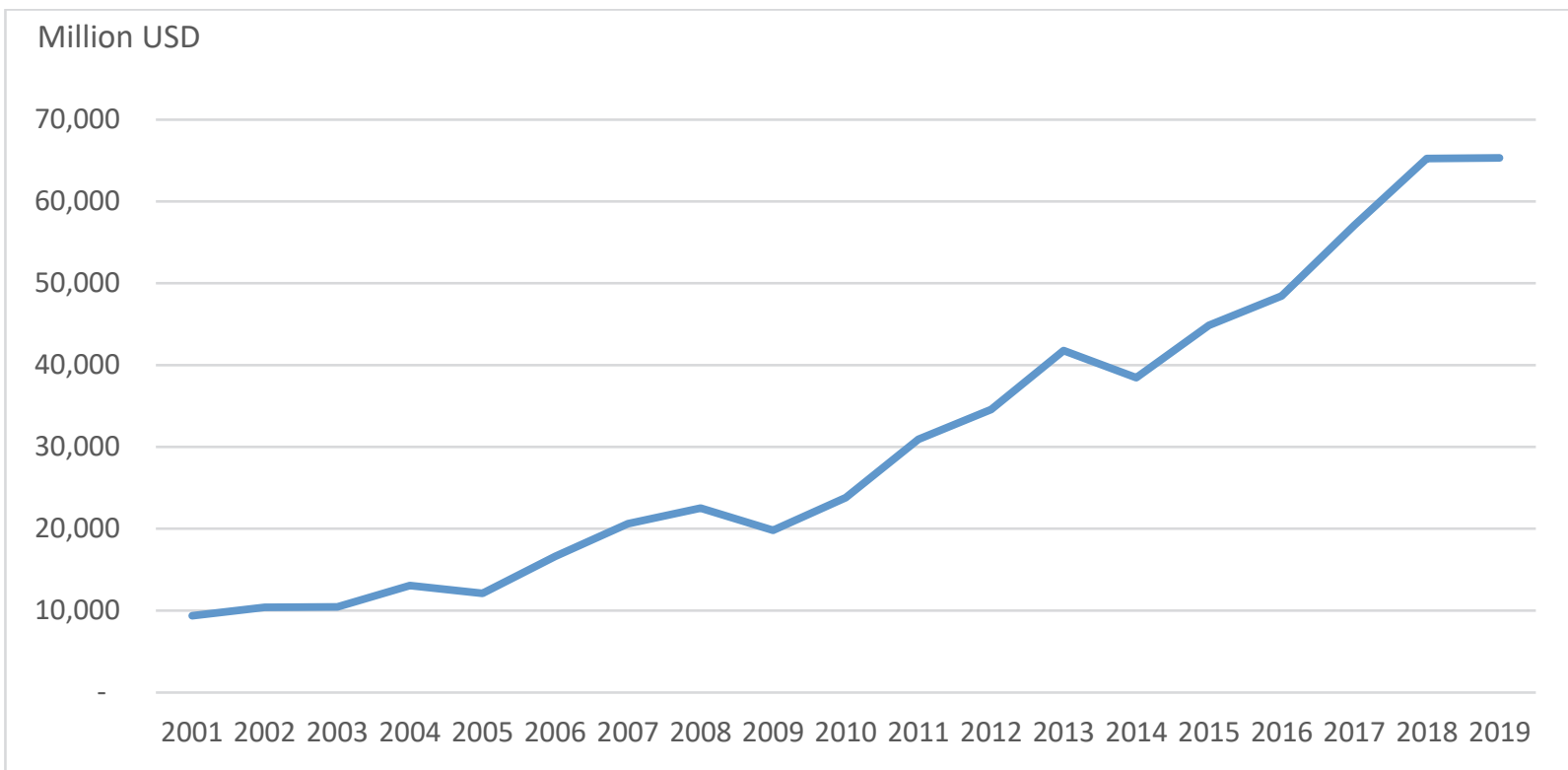

Source: The World Bank (2020)

Fig. 2. The Tourism Revenue of Thailand 2001-2019

The transport and service businesses listed on the Stock Exchange of Thailand are classified into three categories: 1. tourism media services, 2. hotel and recreation, and 3. transport and logistic groups as shown in Fig. 3. Fig. 3 shows the value of all three groups of transport and service industries in the stock market from 2010-2019. It is also likely that the tourism, hotel and 
recreation, and transport and logistic groups are likely to continue to grow. The size of the transportation and logistics sector is likely to fluctuate, but after the liberalization policy of Thailand in regard to foreign companies, the market value of the transportation and logistics sector has increased since 2016. However, when considered in general, it was found that the value of securities in the transport and service industry category from the Stock Exchange of Thailand of the three groups has tended to increase every year from 2017.

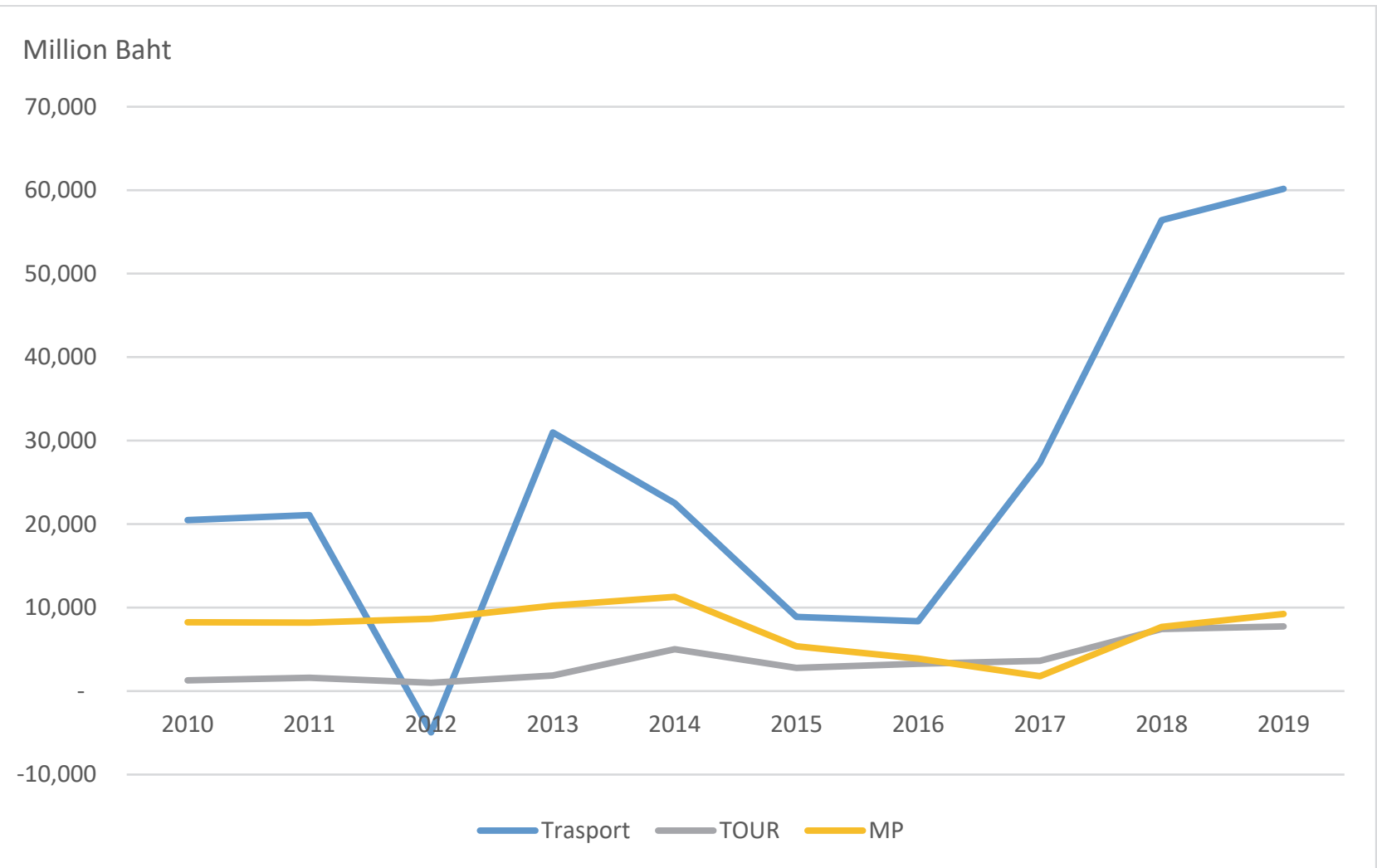

Source: The Stock Exchange of Thailand (2020)

Fig. 3. Value of securities in the transport and service industry category from the Stock Exchange of Thailand from $2010-$ 2019

Due to the expansion of the transport and service industry of Thailand, whether in terms of tourism and service income or the increasing number of tourists, the Thai tourism and service sector of the stock market has also expanded. However, the expansion of Thai service industries in the stock market may be the result of many reasons. In particular, macroeconomic factors may determine the rise and fall of the transport and service industry category in the Thai stock market because the country's stock market is one of the indicators that can reflect the country's economic status and support the performance of supply chain finance (Bui \& Doan, 2020). In addition, Thailand relies heavily on tourism and service businesses and it is also a major source market for the Greater Mekong sub-region (Nonthapot \& Lean, 2015). Consequently, there are large tourism and service companies listed on the Stock Exchange of Thailand. The study of Thailand, which investigates the factors affecting public companies in the Stock Exchange only focuses on companies in the tourism and leisure groups. Therefore, this research aims to study the macroeconomic factors that affect the rate of return of securities in the transport and service industry category of the Stock Exchange of Thailand, and the findings of the research can be used as guidelines for investors in this sector. This study has four sections. The theoretical model and econometric methodologies are explained in section two. The data and empirical results are discussed in section three. Finally, this paper presents conclusions.

\section{Literature Review}

In the study of a multiple regression model based on time series data, the focus is on cointegration analysis. Pesaran et al. (2001) presented the ARDL procedure for cointegration. The concept of ARDL can be used regardless of whether the variable is stationary with I (0) or I (1) or (2) while in the short-term adaptation process, it can also be taken from the ARDL process by short-term adaptation resulting from the combination of short-term changes and long-term balance without data loss. Hence, it can be said that when using the ARDL model, problems can be avoided that can arise from unstable time series data (Nonthapot $\&$ Watchalaanun, 2015). Bahmani-Oskooee et al. (2003) studied the impact of yen devaluation on the major trade balances of 
Japan and its key trading partners using an ARDL approach to cointegration for the short-term and long-term effects. The study found that the devaluation of the yen did not affect the trade balance of the trading partner countries. In Thailand, Boonroung and Chaitip (2011) studied the factors affecting the price of securities in the tourism sector in the Stock Exchange of with ARDL approach. The study was found that the diesel retail prices, exchange rates are relationships with the tourism sector in the Stock Exchange. While, Flannery and Protopapadakis (2002) examined that stock market returns are significantly correlated with price factor as well as economic indicators had significant impacts on the stock returns compared to the pre- and post-crisis periods in German (Celebi \& Hönig, 2019). In regard to the relationship between the stock market economic growth, as mentioned above, previous studies about the factors affecting the stock market revealed that trading volume, oil price, gold price, interest rate, and the currency exchange rate (Baht / US Dollar) should be considered as factors affecting the tourism and service securities of Thailand.

\section{Research Methodology}

\subsection{Data}

This research employs secondary quarterly data from 2010 - 2019. The independent variable is the value of securities in the transport and service industry category of the Stock Exchange of Thailand (Y). This study focuses on only three groups because each group is linked with a component of the tourism industry of Thailand: 1.media services 2.tourism, hotel and recreation and 3.transport and logistics. Hence, these are regarded as the independent variables. For the predetermined variables, we focus on macroeconomic variables. This is based on the literature review and includes the following:

1) Stock Exchange volume in thousand shares (S) from The Stock Exchange of Thailand,

2) Exchange rate in Baht / US dollars (E) from the Bank of Thailand,

3) Gold bullion price in Baht (G) from CEIC-Data,

4) Interest rate percentage (I) from the Bank of Thailand,

5) Diesel oil price in US dollars / Barrel (O) from CEIC-Data.

\subsection{Cointegration Test by Autoregressive Distributed Lag (ARDL)}

According to time series theorem in the study of securities information, the time series data that is used must be stationary before estimation or static data. Therefore, we need to test the stationary data based on the Augmented Dickey-Fuller and PhillipsPerron tests to confirm the level of stationarity. In the case of static data at all levels I(1) or I(0) and I(1), the ARDL method is a popular method presented by Pesaran et al. (2001). In this study, the original model is:

$$
Y_{i, t}=\alpha_{0}+\alpha_{1} S_{i, t}+\alpha_{2} E_{i, t}+\alpha_{3} G_{i, t}+\alpha_{4} I_{i, t}+\alpha_{5} O_{i, t}+\varepsilon_{t}
$$

where $i$ is a category of value of securities in the transport and service industry from the Stock Exchange of Thailand. $i=1$ denotes media services, $i=2$ represents tourism and recreation and $i=3$ represents transport and logistics. Due to the long-term relationship, when all variables were tested by unit root test. If all time-series data were stationary with $\mathrm{I}(0)$, $\mathrm{I}(1)$ or mix, we can employ the co-integration process by the autoregressive distributed lag (ARDL). The ARDL cointegration was presented from Eq. (1) and adapted into Eq. (2) with the error correction model (UECM) as the marginal changes with the lag - 1 difference operator.

$$
\begin{aligned}
& \Delta Y_{i, t}=\alpha_{i}+\sum_{i=1}^{p-1} \beta_{1} \Delta Y_{i, t-1}+\sum_{i=1}^{q-1} \beta_{2} \Delta S_{i, t-1}+\sum_{i=1}^{r-1} \beta_{3} \Delta E_{i, t-1}+\sum_{i=1}^{s-1} \beta_{4} \Delta G_{i, t-1}+\sum_{i=1}^{m-1} \beta_{5} \Delta I_{i, t-1}+\sum_{i=1}^{n-1} \beta_{6} \Delta O_{i, t-1} \\
& +\theta_{1} Y_{i, t}+\theta_{2} S_{i, t}+\theta_{3} E_{i, t}+\theta_{4} G_{i, t}+\theta_{5} I_{i, t}+\theta_{6} O_{i, t}+v_{i, t},
\end{aligned}
$$

where $\alpha, \beta_{1}-\beta_{6}$ parameters of independent variable are, $\theta_{1}-\theta_{6}$ are parameter to test cointegration, $v_{\mathrm{t}}$ is error term. From Eq. (2), the parameters of $\theta_{1}-\theta_{6}$ are values that can be used to find long-term balanced relationships. The hypothesis in the test is

$$
\begin{aligned}
& \mathrm{H}_{0}: \theta_{1}=\theta_{2}=\theta_{3}=\theta_{4}=\theta_{5}=\theta_{6}=0 \\
& \mathrm{H}_{1}: \theta_{1} \neq \theta_{2} \neq \theta_{3} \neq \theta_{4} \neq \theta_{5} \neq \theta_{6} \neq 0
\end{aligned}
$$


To test the hypothesis, we used the critical value employed by Sam et al. (2009) in case III (unrestricted intercept and no trend) with the F-stat. When the F-stat for I(0) or I(1) series is above the F-critical value, we will accept the $\mathrm{H}_{1}$ or alternative hypothesis. This means the variables are cointegrated. In contrast, we will accept the null hypothesis $\left(\mathrm{H}_{0}\right)$ when the F-stat is lower than the F-critical value, which means the variables are not cointegrated. We can then confirm that the model has a long-run relationship or is integrated after we have accepted the alternative hypothesis. The ARDL long- run model is presented as Eq. (3) and the ARDL short- run model is shown in Eq. (4) where $\alpha_{i}$ is the constant, $\beta_{1^{-}} \beta_{6}$ are coefficients of the independent variables and $\varepsilon$ is the error term. For the lag order, this study employs the Akaike Information criterion (AIC).

$$
\Delta Y_{i, t}=\alpha_{i}+\sum_{i=1}^{p-1} \beta_{1} \Delta Y_{i, t-1}+\sum_{i=1}^{q} \beta_{2} \Delta S_{i, t-1}+\sum_{i=1}^{r} \beta_{3} \Delta E_{i, t-1}+\sum_{i=1}^{s} \beta_{4} \Delta G_{i, t-1}+\sum_{i=1}^{m} \beta_{5} \Delta U_{i, t-1}+\sum_{i=1}^{n} \beta_{6} \Delta O_{i, t-1}+\varepsilon_{i, t},
$$

where the cointegration and the ARDL long-run estimation from equation 2 were confirmed, the Vector error-correction model (VECM) including the error correction term $\left(\varepsilon_{t}\right)$ from Eq. (3) was created. The model is shown as Eq. (4). This equation can explain the short-run deviations of the series from the long-run equilibrium path. If the result from Eq. (2) is cointegrated, the short-run model is as follows:

$$
\ln Y_{i, t}=\alpha_{0}+\sum_{j=1}^{q-1} \alpha_{1} \Delta S_{t-j}+\sum_{i=1}^{r-1} \alpha_{2} \Delta E_{t-i}+\sum_{i=1}^{s-1} \alpha_{3} \Delta G_{t-i}+\sum_{i=1}^{m-1} \alpha_{4} \Delta U_{t-i}+\sum_{i=1}^{n-1} \alpha_{5} \Delta O_{t-i}+\alpha_{6} \varepsilon_{i, t-1}+v_{i, t},
$$

where $\alpha_{0}$ is the constant, $\Delta$ denotes the differences, $v_{t}$ the disturbance term, $\varepsilon_{t-1}$ is the lagged error correction term generated from the long run error term from Eq. (3). The short -run equation is presented by $\alpha_{1}-\alpha_{5}$ based on Wald test to indicate shortrun casual effects between the dependent variables and independent variables. In addition, the t-statistic of lagged error correction term $\left(\alpha_{6}\right)$ confirms the short-run deviations of the series from the short run to long-run equilibrium path.

\section{Results}

\subsection{Unit root test}

The results of the unit root test are tests for variables that are used in the analysis of financial crises that affect the yields of the Stock Exchange of Thailand in the transport and service industry category of the Stock Exchange of Thailand. This is confirmation of the qualifying variables whether stationary or non-stationary, considering all 8 variables, including the value of securities in the service industry category $\left(\mathrm{Y}_{1}-\mathrm{Y}_{3}\right)$, stock exchange volume in thousand shares $(\mathrm{S})$, exchange rate $(\mathrm{E})$, gold bullion price $(\mathrm{G})$, interest rate $(\mathrm{I})$, and the diesel oil price $(\mathrm{O})$. The test results are presented in Table 1 . The table shows the results of the unit root test of all 8 variables with the Augmented Dickey-Fuller (ADF) test and Phillips - Perron test (PhillipsPerron, 1988), as per Mackinnon (1996). The test results reveal that $\ln Y_{1}, \ln Y_{3}$ and $\ln I$ variables are stationary at the level or $\mathrm{I}(0)$ while $\ln Y 1, \ln S, \ln E, \operatorname{lnG}, \ln I, \ln \mathrm{O}$ variables cannot support the alternative hypothesis at the level. However, $\ln Y_{1}, \ln S, \ln E$, $\ln G, \ln I, \ln O$ variables support the alternative hypothesis at the first differences with a probability value less than 0.01 , indicating that all $\ln Y 1, \ln S, \operatorname{lnE}, \operatorname{lnG}, \ln I, \operatorname{lnO}$ are stationary at I(1). Therefore, it can be concluded that all variables are stable at $\mathrm{I}(0)$ and I (1) and we can move on to the cointegration process.

Table 1

\begin{tabular}{|c|c|c|c|c|c|}
\hline \multirow[t]{2}{*}{ Variables } & \multicolumn{2}{|c|}{$\mathrm{ADF}$ test $^{1}$} & \multicolumn{2}{|c|}{ Phillips - Perron test ${ }^{1}$} & \multirow{2}{*}{$\begin{array}{c}\text { Stationary } \\
\text { level }\end{array}$} \\
\hline & $\mathrm{I}(0)$ & $\mathrm{I}(1)$ & $\mathrm{I}(0)$ & $\mathrm{I}(1)$ & \\
\hline $\ln Y_{1}$ & -0.53 & $-10.40 * * *[1]$ & -0.40 & $-10.23 * * *$ & $\mathrm{I}(1)$ \\
\hline $\ln Y_{2}$ & $-5.30 * * *[1]$ & $-10.98 * * *[1]$ & $-5.24 * * *[3]$ & $-13.33 * * *[3]$ & $\mathrm{I}(0)$ \\
\hline $\ln \mathrm{Y}_{3}$ & $-4.05 * * *[2]$ & $-9.21 * * * \quad[2]$ & $-6.34 * * *[3]$ & $-22.09 * * * \quad[2]$ & $\mathrm{I}(0)$ \\
\hline $\ln S$ & -2.16 & $-6.50 * * * \quad[1]$ & -1.85 & $-5.30 * * * \quad[9]$ & $\mathrm{I}(1)$ \\
\hline $\ln \mathrm{E}$ & -0.53 & $-4.40 * * * \quad[2]$ & -1.52 & $-6.22 * * * \quad[2]$ & $\mathrm{I}(1)$ \\
\hline $\ln G$ & -2.01 & $-4.33 * * * \quad[2]$ & -2.20 & $-7.12 * * * \quad[1]$ & $\mathrm{I}(1)$ \\
\hline $\ln I$ & $-3.32 * * \quad[1]$ & $-4.36 * * * \quad[1]$ & -2.49 & $-4.45 * * * \quad[1]$ & $\mathrm{I}(0)$ \\
\hline $\ln O$ & $-1.11 \quad[2]$ & $-4.82 * * * \quad[2]$ & -1.12 & $-8.53 * * * \quad[1]$ & $\mathrm{I}(1)$ \\
\hline
\end{tabular}

Unit Root Test Results

Note: ${ }^{1}$ MacKinnon (1996) one-sided p-values. Lag order is in [ ].

The asterisks $* * *, * *$ denotes significance at the 1 and 5 percent levels, respectively 
According to Eq. (2), based on $\ln \mathrm{Y}_{i} \mid \ln \mathrm{S}, \ln \mathrm{E}, \ln \mathrm{l}, \ln \mathrm{l}, \ln \mathrm{O}$ are tested by using an ARDL bounds testing procedure. This study employs a maximum order lag of 8 with Akaike information criterion or AIC (Nonthapot \& Watchalaanun, 2015). The ARDL bounds testing estimation results are shown in Table 2 based on case III: unrestricted intercept and no trend. The Fstatistic calculation results from the ARDL bounds testing in the media service; tourism and recreation; transport and logistics categories are 5.37, 5.29 and 11.81, respectively. The results indicate that the estimation results are greater than the 1 percent upper bound critical value. This means the model from Eq. (2) is cointegrated and short and long runs analysis can be conducted.

Table 2

Bounds Test for ARDL Cointegration Test Results

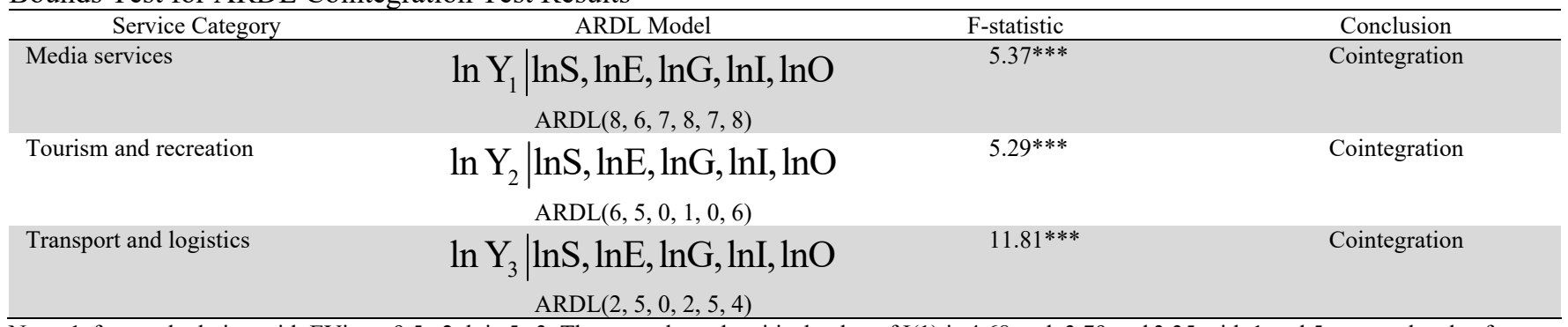

Note: 1 . from calculation with EViews 9.5 2. $\mathrm{k}$ is 5 3. The upper bounds critical value of I(1) is 4.68 and 3.79 and 3.35 with 1 and 5 percent levels of significance, respectively.

In order to confirm the results of the ARDL cointegration test, the stability of the results needs to be demonstrated. Thus, we employ the stability test with cumulative sum (CUSUM) and the cumulative sum of squares (CUSUMsq) of the standardized recursive residuals as proposed by Brown et al. (1975). The plots of both the CUSUM and CUSUMsq test results are presented in Fig. 4 to Fig. 6. The results of the CUSUM indicate that all of three models are generally within the 5\% significance lines or are stable while the results from the CUSUMsq test of media services and tourism, hotel and recreation are within the 5\% significance lines. However, the transport and logistic category deviates from the area of 5\% significance lines, which is lesser. Therefore, this study can confirm that the economic factors affecting the value of securities in the transport and service industry category from the Stock Exchange of Thailand are coingrated in 1.media services 2.tourism, hotel and recreation 3.transport and logistics. In addition, after we accept the results of the ARDL cointegration test and obtain confirmation of stability, the long-run estimation results are as presented in Table 3.
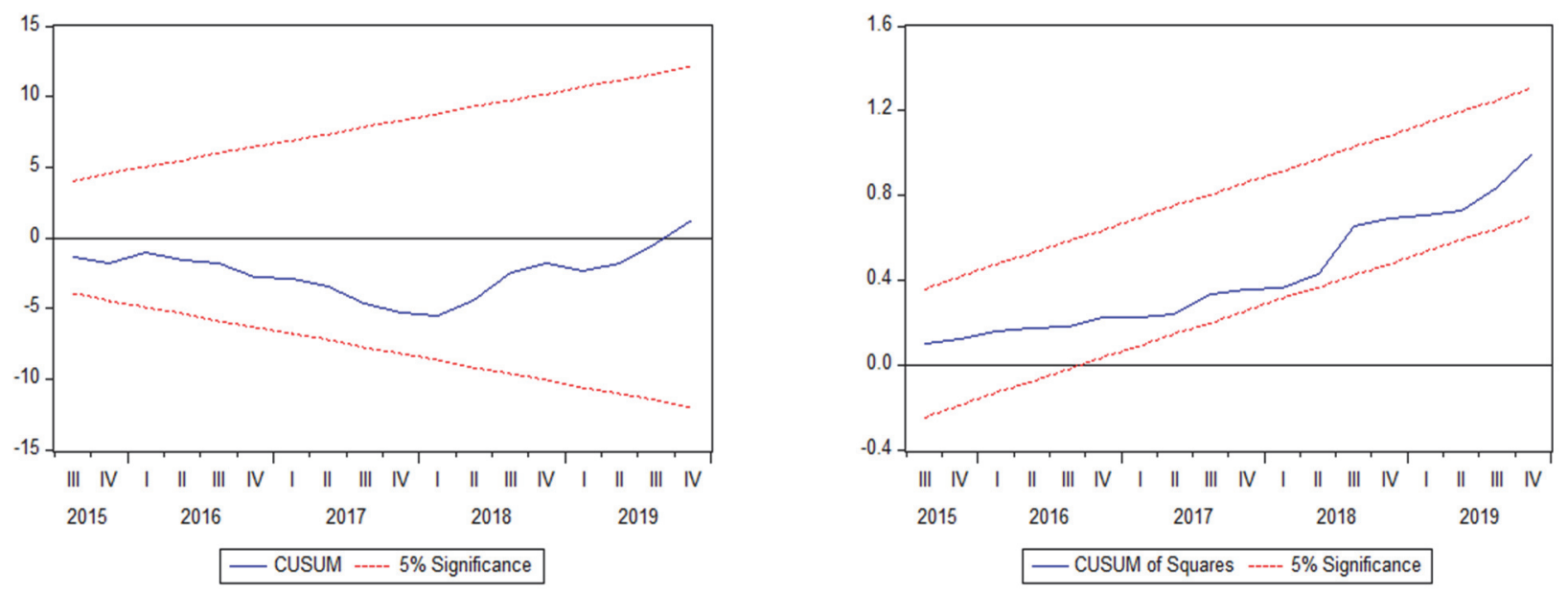

Fig. 1. CUSUM and CUSUM of Square for ARDL Model of Media services 

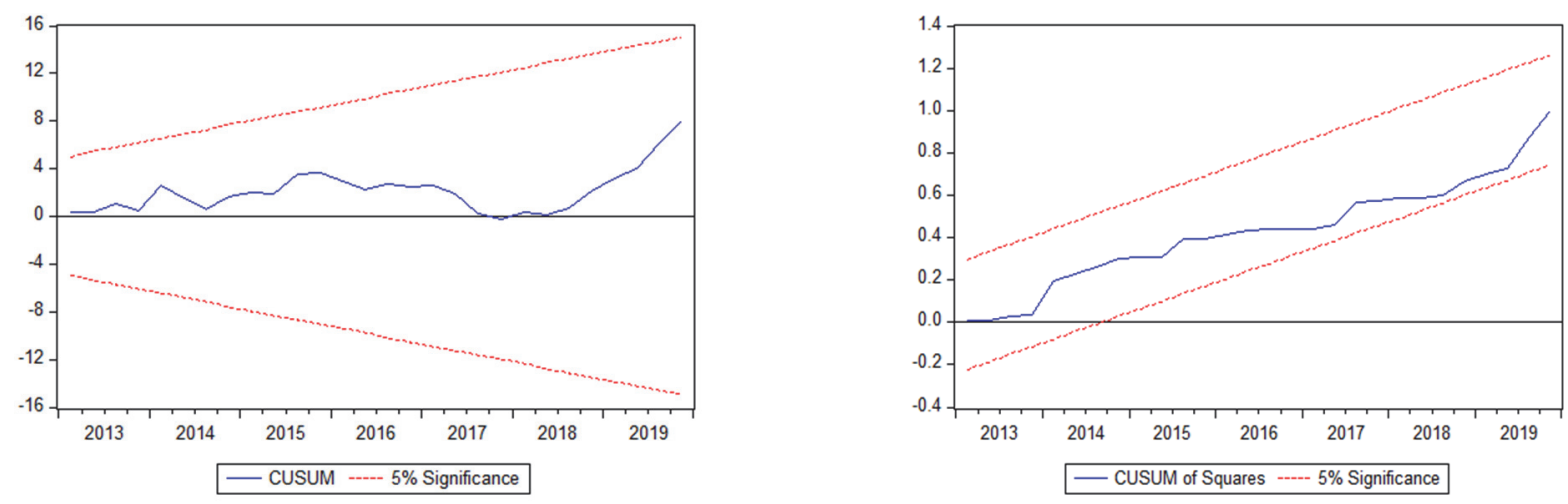

Fig. 5. CUSUM and CUSUM of Square for ARDL Model of Tourism, Hotel and Recreation
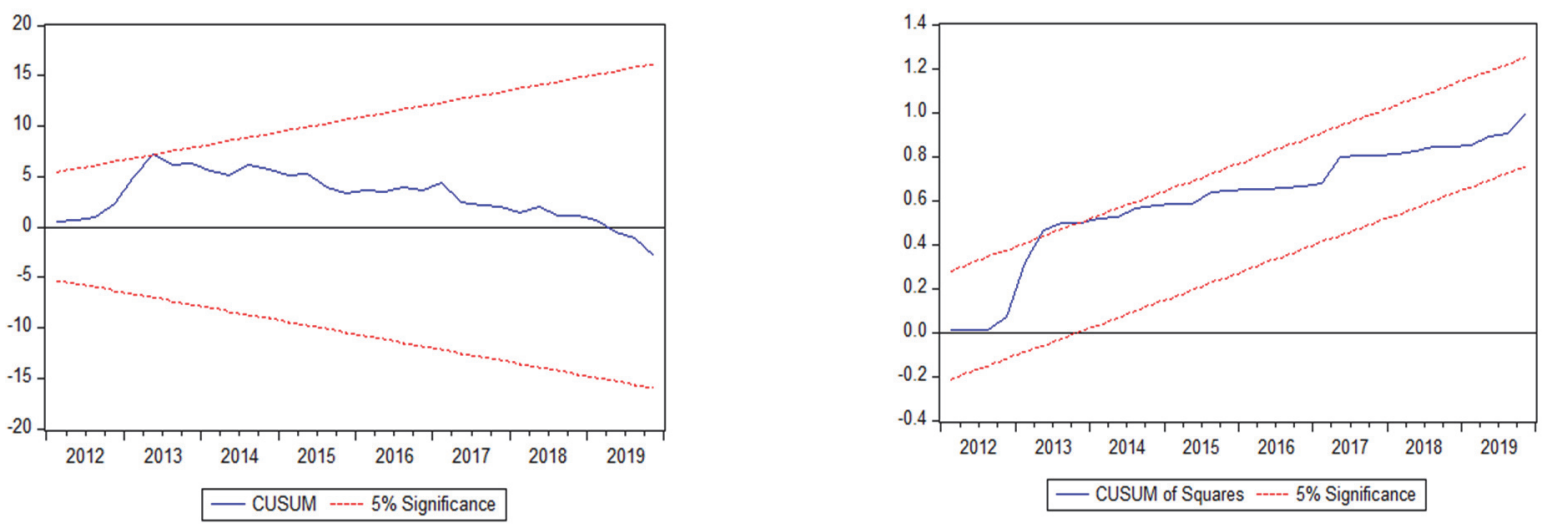

Fig. 6. CUSUM and CUSUM of Square for ARDL Model of Transport and Logistics

Table 3

ARDL Long-Run Estimation Results

\begin{tabular}{lccccccc}
\hline Service Categories & $\begin{array}{c}\text { Dependent } \\
\text { variables }\end{array}$ & \multicolumn{7}{c}{ Independent Variables } \\
\cline { 3 - 8 } & & $\ln \mathrm{S}$ & $\ln \mathrm{E}$ & $\operatorname{lnG}$ & $\ln \mathrm{l}$ & $\operatorname{lnO}$ & Constant \\
\hline Media services & $\ln \mathrm{Y}_{1}$ & $0.95(2.02)$ & $-8.66^{* * *}(-4.68)$ & $-1.15^{* *}(-2.21)$ & $1.13(0.97)$ & $0.20(0.40)$ & $37.41^{* *}$ \\
& $1.62^{* * *}(4.01)$ & $-3.19(-1.72)$ & $-2.94^{* * *}(4.87)$ & $-0.07(-0.05)$ & $0.25(0.44)$ & $30.766^{* * *}$ \\
$\begin{array}{l}\text { Tourism, hotel and } \\
\text { recreation }\end{array}$ & $\ln \mathrm{Y}_{2}$ & $1.82)$ \\
$\begin{array}{l}\text { Transport and } \\
\text { logistics }\end{array}$ & $\ln \mathrm{Y}_{3}$ & $0.43(1.82)$ & $-2.16^{* *}(-1.96)$ & $-1.32^{* * *}(3.61)$ & $2.70^{* * *}(2.77)$ & $-0.68^{* *}(-2.37)$ & $22.39^{* * *}$ \\
& & & & & $(3.55)$ \\
\hline
\end{tabular}

Note: $t$ - statistics is parentheses. The asterisk ${ }^{* * *},{ }^{* *}$ denotes significance at the 1 and 5 percent levels, respectively.

Table 3 shows the long-run estimation results for macroeconomic factors that affect the value of securities in the tourism and service category of the Stock Exchange of Thailand based on the ARDL procedure. The results reveal that the exchange rate factor has a negative effect on the value of securities in the media service group at the 1 percent level and also has a negative effect on the value of securities in the transport and logistics group at the 5 percent significance level while the gold bullion price factor negatively affects the value of securities in the tourism, hotel and recreation, and transport and logistic groups at the 1 percent level; and has a negative effect on the value of securities in the media service group at the 5 percent significance level. The interest rate factor only has a positive effect on the value of securities in the transport and logistic group at the 1 percent significance level. In addition, the stock exchange volume in thousand shares factor has a positive effect on the tourism, hotel and recreation group at the 1 percent level while the diesel oil price factor negatively affects the transport and logistics group at the 1 percent level. 


\subsection{Short-Run Coefficient Test}

The short-run estimation results are presented in Table 4. The macroeconomic factors, which are the stock exchange volume in thousand shares, the exchange rate, the gold bullion price, the interest rate and diesel oil price cause deviations between the short-run and long-run effects on media services; tourism, hotel and recreation and; transport and logistics groups of tourism and service category of the Stock Exchange of Thailand. The term equilibriums of macroeconomic factors deviate between the short-run and long run for media services; tourism, hotel and recreation and the transport and logistics groups by approximately $204,115,145$ percent in each time period, respectively $\left(\varepsilon_{t-1}=-2.04,-1.15,-1.45\right)$.

\section{Table 4}

Error Correction Coefficients in terms of ARDL Model

\begin{tabular}{|c|c|c|c|}
\hline \multirow{2}{*}{$\begin{array}{c}\text { Independent } \\
\text { variables }\end{array}$} & \multicolumn{3}{|c|}{ Service Industry Categories / Dependent Variables / Coefficients } \\
\hline & Media services & Tourism, hotel and recreation & Transport and logistics \\
\hline Constant & $76.48 * * *$ & $35.50 * * *$ & $32.56^{* * *}$ \\
\hline$\Delta \ln \mathrm{S}_{\mathrm{t}}$ & $3.70 * * *$ & $2.66 * *$ & \\
\hline$\Delta \ln \mathrm{S}_{\mathrm{t}-1}$ & $-2.98 * * *$ & 0.38 & 0.18 \\
\hline$\Delta \ln \mathrm{S}_{\mathrm{t}-2}$ & $-3.63 * * *$ & 0.80 & -1.55 \\
\hline$\Delta \ln \mathrm{S}_{\mathrm{t}-3}$ & 0.10 & 0.86 & -1.74 \\
\hline$\Delta \ln \mathrm{S}_{\mathrm{t}-4}$ & $-2.83 * * *$ & $2.83 * *$ & -1.16 \\
\hline$\Delta \ln \mathrm{S}_{\mathrm{t}-5}$ & -2.12 & & \\
\hline$\Delta \ln \mathrm{E}_{\mathrm{t}}$ & 0.17 & & \\
\hline$\Delta \ln \mathrm{E}_{\mathrm{t}-1}$ & $7.00 * *$ & & \\
\hline$\Delta \ln \mathrm{E}_{\mathrm{t}-2}$ & $16.72 * * *$ & & \\
\hline$\Delta \ln \mathrm{E}_{\mathrm{t}-3}$ & 2.69 & & \\
\hline$\Delta \ln \mathrm{E}_{\mathrm{t}-5}$ & $22.55 * * *$ & & \\
\hline$\Delta \ln \mathrm{E}_{\mathrm{t}-6}$ & $14.37 * * *$ & & \\
\hline$\Delta \ln G_{t}$ & 0.69 & 2.09 & $-3.80 * *$ \\
\hline$\Delta \ln G_{t-1}$ & $4.99 * * *$ & & $3.55^{* *}$ \\
\hline$\Delta \ln _{\mathrm{t}-2}$ & -1.94 & & \\
\hline$\Delta \ln G_{t-3}$ & $5.74 * * *$ & & \\
\hline$\Delta \ln _{\mathrm{t}-4}$ & -0.20 & & \\
\hline$\Delta \ln \mathrm{G}_{\mathrm{t}-5}$ & $2.89 * *$ & & \\
\hline$\Delta \ln \mathrm{G}_{\mathrm{t}-6}$ & $-2.68 * *$ & & \\
\hline$\Delta \ln _{\mathrm{t}-7}$ & $3.95 * * *$ & & \\
\hline$\Delta \ln \mathrm{I}_{\mathrm{t}}$ & 0.58 & & 1.75 \\
\hline$\Delta \ln \mathrm{I}_{\mathrm{t}-1}$ & $10.92 * *$ & & -1.67 \\
\hline$\Delta \ln \mathrm{I}_{\mathrm{t}-2}$ & $-25.00 * * *$ & & -5.58 \\
\hline$\Delta \ln \mathrm{I}_{\mathrm{t}-3}$ & 4.28 & & 0.53 \\
\hline$\Delta \ln \mathrm{I}_{\mathrm{t}-3}$ & -0.46 & & $-10.46 * * *$ \\
\hline$\Delta \ln \mathrm{I}_{\mathrm{t}-5}$ & $-10.05 * * *$ & & \\
\hline$\Delta \ln \mathrm{I}_{\mathrm{t}-6}$ & 4.49 & & \\
\hline$\Delta \ln _{\mathrm{t}}$ & -1.33 & -0.44 & \\
\hline$\Delta \ln \mathrm{O}_{\mathrm{t}-1}$ & -0.07 & 0.46 & \\
\hline$\Delta \operatorname{lnO}_{\mathrm{t}-2}$ & $-3.18 * * *$ & $2.41 * *$ & \\
\hline$\Delta \ln \mathrm{O}_{\mathrm{t}-3}$ & -0.02 & $-2.53 * *$ & \\
\hline$\Delta \operatorname{lnO}_{\mathrm{t}-4}$ & $-1.47 * *$ & -0.52 & \\
\hline$\Delta \ln \mathrm{O}_{\mathrm{t}-5}$ & $-1.60 * *$ & $4.77 * * *$ & \\
\hline$\Delta \operatorname{lnO}_{\mathrm{t}-6}$ & 0.16 & & \\
\hline$\Delta \ln \mathrm{O}_{\mathrm{t}-7}$ & $1.43^{* *}$ & & \\
\hline$\varepsilon_{\mathrm{t}-1}$ & $-2.04 * * *$ & $-1.15 * * *$ & $-1.45 * * *$ \\
\hline Diagnostic test & $\mathrm{R}^{2}=0.90$ S.E. $=0.33$ D.W. $=$ & $\mathrm{R}^{2}=0.76$ S.E. $=0.76$ D.W. $=$ & $\mathrm{R}^{2}=0.69$ S.E. $=0.57$ D.W. $=$ \\
\hline
\end{tabular}




\section{Conclusion and Policy Recommendations}

The main objective of the study is to examine the macroeconomic factors affecting the tourism and service category of the Stock Exchange of Thailand. The categories comprise 1.media services; 2.tourism, hotel and recreation, and 3.transport and logistics groups. This study employs the ARDL bounds testing approach. The results reveal that the media services; tourism, hotel and recreation and; transport and logistics groups of the tourism and service category of the Stock Exchange of Thailand are cointegrated with the stock exchange volume in thousand shares, the exchange rate, the gold bullion price, the interest rate and the diesel oil price. Hence, this study found that the long-term equilibriums of macroeconomic factors deviate from the shortrun for the media services; tourism, hotel and recreation, and transport and logistics groups.

$\mathrm{T}$ this study focused on long-run estimations. The gold bullion price factor has become a key factor that affects the tourism and service category of the Stock Exchange of Thailand because it negatively affects the value of securities in the media service; tourism, hotel and recreation, and transport and logistic groups. The results indicate that investors consider the gold bullion price as a competitor factor when making the decision to invest in securities in the transport and service industry category of the Stock Exchange of Thailand. The exchange rate factor has a negative effect on the value of securities in the media service and transport and logistics groups. This evidence reveals the impact of the exchange rate between Thai Baht and the US Dollar. When the Thai baht depreciates, investors and speculators are slow to invest in the Stock Exchange of Thailand as the categories of media service and transport and logistics are dependent on international trade. Thus, the results show a negative sign. The value of securities in the transport and logistics group has a positive effect on the interest rate factor at the 1 percent significance level. This indicates that investors focus on the transport and logistic sector response with is an important factor. In contrast, the diesel oil price factor negatively affects the transport and logistics group of the Stock Exchange of Thailand. The results show causality between transport and logistics and the diesel oil price because if the price of oil increases, it will impact transport and logistics in Thailand and it can affect the value of the transport and logistics group in the transport and service industry at the Stock Exchange of Thailand. In addition, the stock exchange volume in thousand shares factor has a positive effect on the tourism, hotel and recreation group at the 1 percent level. When we focus on the tourism, hotel and recreation group of the transport and service industry at the Stock Exchange of Thailand, it was found that there were eight companies in the hotel category while there were six recreation companies. These companies are related to long term investment and real estate. The results revealed that the tourism, hotel and recreation group was related to the stock exchange volume in the same direction. From the study results, the gold bullion price factor is a major factor in determining the long run. This is because investors have the opportunity to invest in the short term or the long term. Hence, gold is an alternative to investment in the tourism and service category of the Stock Exchange of Thailand. Regarding the macroeconomic factors, potential investors in the transport and logistics groups should focus on the exchange rate, the gold bullion price, the interest rate and the diesel oil price before investing. Furthermore, investors should consider the exchange rate before investing in the media service group of the Stock Exchange of Thailand while for investors in the tourism, hotel and recreation group of the Stock Exchange of Thailand should take into account the stock exchange volume in thousand shares. Moreover, the macroeconomic factors can be viewed from two perspectives. The first view is from the company's perspective. The results reflect which variables have a significant impact on the company in the short-run and the long-run and can assist in both short and long-term policymaking decisions. From the investors' perspective, investors who want to invest in securities in the tourism and service category can check the test results from this study. For example, if short or long-term investors need to consider which macroeconomics factors affect securities in the tourism and service category of the Stock Exchange of Thailand.

\section{References}

Bui, T. N. \& Doan, T-T. T. (2020). Factors influencing supply chain finance of real estate sector: Evidence using GMM estimation. Uncertain Supply Chain Management, 8(3), 439-632.

Boonroung, K. \& Chaitip, P. (2003). Analysis of factors affecting the return of securities in the tourism and recreation groups of the stock exchange of Thailand with the ARDL method. Chiang Mai University Journal of Economics, 15(1), 92-110.

Brown, R.L., Durbin, J. \& Evans, J.M. (1975). Techniques for testing the constancy of regression relations over Time. Journal of the Royal Statistical Society, Series B, 37, 149-163.

CEIC Data (2020). Thailand.

Celebi, K. \& Hönig, M. (2019). The Impact of macroeconomic factors on the German Stock Market: Evidence for the crisis, pre- and post-crisis periods. International Journal of Financial Studies, 29(7), 1-13.

Flanner, M.J. \& Protopapadakis, A. A. (2002). Macroeconomic factors do influence aggregate stock returns. The Review of Financial Studies, 15(3), 751-782.

MacKinnon, J.G. (1996). Numerical distribution functions for unit root and cointegration tests. Journal of Applied Econometrics, 11, 601-618.

Nonthapot, S. (2019). Thai tourists choice of accommodation based on marketing behaviors in Vang Vieng town, Lao People's Democratic Republic. Journal of Environmental Management and Tourism, 10(4). 725-734. 
Nonthapot, S. \& Lean, H.H. (2015). International tourism market analysis in the Greater Mekong Sub-Region: A panel data approach. Pertanika Journal of Social Sciences and Humanities, 23(4), 945-966.

Nonthapot, S. \& Watchalaanun, T. (2015). Relationship between tourism expansion and telecommunication in Thailand. Journal of Advanced Research in Management, 6(1), 33-43.

Nonthapot, S. \& Srichaiyo, P. (2017). The effects of financial crises on tourism in the Greater Mekong Sub-region: Panel ARDL approach. Journal of Environmental Management and Tourism, 8(20), 853-860.

Ozoh, P., \& Abd-Rahman, S. (2017). A procedure for the analysis of multivariate factors affecting electricity consumption. International Journal of Applied Information Systems, 12(9), 8-12.

Pablo-Romero, M.D.P., Sánchez-Braza, A. \& Sánchez-Rivas, J. (2019). Tourism and electricity consumption in 9 European countries: a decomposition analysis approach. Current Issues in Tourism.

Pesaran, M. H., Shin, Y., \& Smith, R. J. (2001). Bounds testing approaches to the analysis of level relationships. Journal of Applied Econometrics, 16(3), 289-326.

Phillips, P. C., \& Perron, P. (1988). Testing for a unit root in time series regression. Biometrika, 75(2), $335-346$.

Sam, C. Y., McNown, R., \& Goh, S. K. (2019). An augmented autoregressive distributed lag bounds test for cointegration. Economic Modelling, 80, 130-141.

The Stock Exchange of Thailand. (2020). Stock Market Index.

The World Bank. (2020). International Tourism Receipts in Thailand 2014 - 2019.

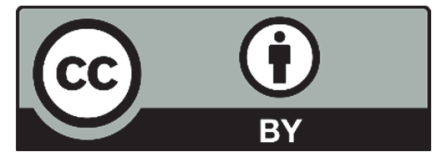

(C) 2020 by the authors; licensee Growing Science, Canada. This is an open access article distributed under the terms and conditions of the Creative Commons Attribution (CC-BY) license (http://creativecommons.org/licenses/by/4.0/). 